Lucia Mokra, Ph.D., Associate Professor

Comenius University in Bratislava, Slovak Republic

\title{
THE SLOVAK REPUBLIC'S POSITIVE OBLIGATION REGARDING HUMAN RIGHTS AND AGAINST RACIAL DISCRIMINATION ${ }^{1}$
}

\begin{abstract}
Summary
The article analyses the positive obligation of a sovereign state regarding the individual's human rights and the enforcement of those rights. The concept of state liability in enforcing the state's positive obligation has developed differently at the international and European levels. International law relied mainly on a diplomatic approach until changes were made to the UN system, in which committees operate as semi-judicial bodies. The European system - established mainly at the Council of Europe - incorporates a stronger legal mechanism for the judicial enforcement of the individual's human rights but there are obstacles to exercising European Court of Human Rights judgements. The content analysis of the case law has been employed to provide comparative insights into the enforcement of positive obligation in human rights and to formulate recommendations based on the principles of good practice.
\end{abstract}

Keywords: human rights, international treaties, supremacy of law, positive obligation

\section{Introduction}

Equality of opportunity and the prohibition of discrimination are guaranteed by the Constitution of the Slovak Republic and set out in detail in several legal acts. Fundamental human rights and freedoms have been guaranteed in the Slovak Republic since it was founded, particularly in Article 12, paragraph 2 of the Constitution: "Basic rights and freedoms on the territory of the Slovak Republic are guaranteed to everyone regardless of sex, race, colour of skin, language, faith and religion, political, or other thoughts, national or social origin, affiliation to a nation, or ethnic group, property, descent, or any other status. No one may be harmed, favoured, or discriminated against on these grounds." Here, the Constitution refers to international human rights treaties adopted mainly within the UN and the existing positive obligation.

The aim of this paper is to provide comparative insights into case law relating to the enforcement of positive obligation in the human rights domain in Slovakia, focusing particularly on non-discrimination in regard to race, and to formulate recommendations based on the principle of good practice.

1 This paper was written as a part of project APVV-16-0540 "Human Rights and Sustainable Development in the EU External Relations". 


\section{The Slovak Republic and the principle of the supremacy of international treaties}

Initially, the supremacy principle regarding international law was set out rather generally in the Constitution of the Slovak Republic through Constitutional Act No. 460/1992 Coll, Article 11:

International treaties on human rights and fundamental freedoms, which had been ratified by the Slovak Republic and announced according to the law, are supreme to law, if and when they provide higher protection of human rights and freedoms.

The Slovak Republic has recognised its international obligations in the human rights domain since its foundation, consequently, a more precise definition was later added to the national Constitution, as the country developed its constitutional framework regarding international relations, membership of international organisations and ambitious integration in the European regional context. This was the most extensive amendment to the Constitution, in the form of Constitutional Act No. 90/2001 Coll. of Laws, amending the Constitution, Act No. 460/1992 Coll.

The regulation of the supremacy principle applicable to international human rights treaties in the Slovak legal system is stipulated in Article 7 paragraphs 4 and 5 of the Constitution:

(4) In order for any international treaties on human rights and fundamental freedoms, international political treaties, international treaties of military nature, international treaties establishing the membership of the Slovak Republic in international organizations, international economic treaties of general nature, international treaties whose execution requires a law and international treaties which directly constitute rights or obligations of natural persons or legal persons to be valid, an approval of the National Council of the Slovak Republic is required prior to their ratification.

(5) International treaties on human rights and fundamental freedoms, international treaties whose executions does not require a law and international treaties which directly establish rights or obligations of natural persons or legal persons and which were ratified and promulgated in a manner laid down by law shall have primacy over the laws.

The constitution leaves us in no doubt that internationally the Slovak Republic has a positive obligation under the international human rights treaties, as stated in Article 7, paragraphs 4 and 5. The Constitutional Court of the Slovak Republic has confirmed this:

The Constitutional Court from the beginning of its existence in accordance with the principle pacta sunt servanda constantly rules that human rights and freedoms as granted by the Constitution have to be interpreted and implemented in the context and the sense of international treaties on human rights and fundamental freedoms (PL ÚS 5/93, PL ÚS 15/98, PL ÚS 17/00). This means also in situations when the Court was not forced to directly rule on violation of the Convention or other 
international treaty on human rights and freedoms, the Court always, if not excluded by the Constitution itself, took into consideration also the content of such international treaties and related case law, when interpreting content of human rights and freedoms as granted in the Constitution (II. ÚS 55/98). ${ }^{2}$

\subsection{Protection of human rights and fundamental freedoms in Slovakia on the basis of the UN treaties}

Human rights protection is one of the fundamental principles of international law, as stated in the UN Charter and in the Universal Declaration of Human Rights. As such, it has to be observed in other international and national documents and treaties, as well. The relevant UN treaties focusing on specific areas of human rights provide a more precise definition of this principle, and the content of the positive obligation. The obligation of the signatory party of such an international human rights treaty is considered a positive obligation, that is, the obligation to grant and protect human rights on the sovereign territory of the signatory party, based on the national constitutional regulation. ${ }^{3}$

As international human rights treaties are sources of law in the Slovak Republic, we aim to analyse Slovakia's fulfilment of its positive obligation under these treaties. The Constitutional Court of the Slovak Republic has ruled, as follows: "International human rights treaties enjoy specific position in the system of legal sources in the Slovak Republic. According to conditions set out in article 11 of the Constitution of the Slovak Republic, these are supreme to laws but not to the Constitution." ${ }^{4}$

Internationally, a country's fulfilment of positive obligation is considered by means of a periodic review aimed at identifying problems and recommending potential legislative amendments to the signatory party and the effective use of application tools and instruments. Competency to review human rights implementation and prevent violation, inequality and discrimination lies with the Human Rights Council, established according to UN General Assembly Resolution No. 60/251 of 2006. As stated in the Resolution, "the Council should address situations of violations of human rights, including gross and systematic violations, and make recommendations thereon. It should also promote the effective coordination and the mainstreaming of human rights within the United Nations system". As Fridrich noted, "proceedings in case of individual applications are based

2 Finding of the Constitutional Court of the Slovak Republic, file ref. No. II. ÚS 5/02, Decision of 21 May 2003. Collection of CC SR Findings, $1^{\text {st }}$ half of the year, 2003, p. 284

3 See more: Fridrich B. (ed.), Ústavné garancie ludských práv [Constitutional guaratees of human rights]. Bratislava: Law faculty, CU, 2013.

4 Finding of the Constitutional Court of the Slovak Republic, file ref. No. II. ÚS 91/1991, Decision of 16 December 1999. Collection of CC SR Findings, $2^{\text {nd }}$ half, 1999, p. 672

5 UN General Assembly Resolution No. 60/251 of 2006. Available at: https://www2.ohchr.org/ english/bodies/hrcouncil/docs/A.RES.60.251_En.pdf [last viewed October 10, 2019]. 


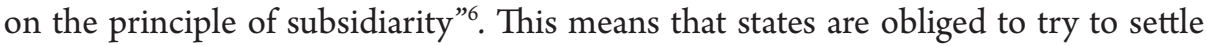
the dispute in a friendly manner, if not, a review is undertaken.

Since 2007, the periodic review has consisted of the submission reports on the state of human rights in the country of the signatory party every four-and-a-half years. Slovakia's first universal periodic review was discussed by the government in 2009. Ninety-one recommendations were delivered. The last universal periodic review covered the period of 2012-2016. The number of recommendations was very similar. The number of individual complaints was rising. The final output of the committee's work in individual cases comes in the form of an opinion. Opinions can be considered decisions by an international body, because they have individual effects (decision in merit, res iudicata at the national level) and general effects for the signatory country of both a legal character (obligation to remedy and legal representation costs) and a political character (recommendations for amendments to national legislation, implementation recommendations). In Slovakia's case, practical implementation of the conclusions and recommendations contained in the Opinion occurs infrequently and is restricted by national legislation.

\section{The Slovak Republic and UN Committee decisions on the prohibition of racial discrimination}

Since 1993, the UN Committees have received 17 individual complaints relating to discrimination. In eight cases, opinions were issued. Most of the opinions concerned the violation of human rights on the basis of racial and gender discrimination. In the current article, we focus only on UN Committee decisions relating to racial discrimination which is of key interest to both the UN and the EU (on 10 October 2019, the EU Commission issued a reasoned opinion to Slovakia urging it to comply with EU rules on the equal treatment of Roma schoolchildren ${ }^{7}$ ). Three opinions were issued. Bearing in mind the number of submissions to other human rights organisations (such as the Council of Europe), this figure suggests structural errors in the protection of individual rights.

The non-discrimination obligation as set out in the International Convention on Elimination of All Forms of Racial Discrimination has been incorporated into Slovakia's Anti-Discrimination $\mathrm{Law}^{8}$, but it is also reflected in legislation on education, health and social insurance, and so on.

6 Fridrich B. Human Rights and Freedoms in the Constitution of the Slovak Republic. In: Constitutional system of the EU member state: The Slovak Republic. Bratislava: VO UK, 2018, p. 101 .

7 European Commission: October infringements package: key decisions. Available at: https://europa. eu/rapid/press-release_INF-19-5950_en.htm [last viewed October 10, 2019].

8 Act No. 365/2004 Coll. of laws on equal treatment is some areas and on protection before discriminaton and on amendments and changes of some acts (Anti-discrimination Act). Available at: https://www.ilo.org/wcmsp5/groups/public/---ed_protect/---protrav/---ilo_aids/documents/ legaldocument/wcms_128039.pdf [last viewed September 20, 2019]. 
The International Convention on Elimination of All Forms of Racial Discrimination was signed by the Czechoslovak Socialistic Republic on 7 March 1966 and ratified, with reservations regarding Articles 17 and 22. It was deposited with the UN on 29 December 1966. According to Article 19, it became valid and effective on 4 January 1969. This was announced in a Notice of the Minister of Foreign Affairs on 15 August 1974 and published in the Official Journal with No. 95/1974 Coll. With succession to international treaties, the Slovak Republic became a signatory party to the Convention on 28 May 1993 with retroactive effect to the date of its foundation on 1 January 1993.

In the Koptová review ${ }^{9}$, the Committee assessed a complaint by Anna Koptová, a Slovak citizen of Roma ethnicity and director of the Office for the Legal Protection of Ethnic Minorities in Slovakia - Dobrá rómska víla Kesaj foundation in Košice (Košice Legal Defence Foundation) - who had complained of the violation of Articles 2 to 6 of the Convention on Elimination of All Forms of Racial Discrimination. As she informed the Committee, in 1981, seven Romany families had come to work at an agricultural cooperative and were awarded permanent residency in the municipality of Krásny Brod (now Rokytovce, and Nagov). When the agricultural cooperative ceased operations at the end of 1989, the Romany families lost their jobs and were compelled to leave the cooperative. In May 1991, the Romany families returned to the municipalities where they were legally registered, Rokytovce and Nagov. Although the families had raised sufficient money to do so, no village allowed them to place their trailer on its territory. On 21 July 1997, dwellings built and occupied by the Romany families in the municipality of Cabiny were set on fire. No perpetrator was identified.

On 8 June 1997, the Municipal Council of Rokytovce enacted resolution No. 21, which expressly forbade the Romany families from settling in the village and threatened them with expulsion should they try to settle there. On 16 July 1997, the Municipality of Nagov adopted resolution No. 22, which forbade Roma citizens from entering the village or settling in shelters in the village district. The Košice Legal Defence Foundation sent a letter to the General Prosecutor's Office in Bratislava requesting an investigation into the legality of Resolutions No. 21 and No. 22.

On 24 November 1997, the Košice Legal Defence Foundation submitted an application to the Constitutional Court of the Slovak Republic requesting the annulment of both resolutions. In its decision of 18 December 1997, the Constitutional Court dismissed the submission on the grounds that, as a legal person, the Košice Legal Defence Foundation could not have suffered an infringement of the constitutional rights set forth in its application, since those rights were designed to protect only natural persons.

9 Communication No. 13/1998 of the Committee on the Elimination of Racial Discrimination. CERD/C/57/D/13/1998, 2000. Available at: https://minorityrights.org/wp-content/uploads/ old-site-downloads/download-372-Anna-Koptova-v.-Slovak-Republic.pdf and https://www.equalrightstrust.org/sites/default/files/ertdocs//Koptova\%20v\%20Slovakia\%20_ access\%20to\%20good\%20and\%20services_.pdf [last viewed September 20, 2019]. 
On 5 May 1998, Ms. Koptová, together with Miroslav Lacko (another employee of the Košice Legal Defence Foundation) and Jan Lacko, one of the Romany citizens whose dwellings were destroyed on 21 July 1997, filed another submission before the Constitutional Court. This submission challenged the Nagov resolution on the grounds that it unlawfully restricted the freedom of movement and residence of a group of people solely on the grounds of their Roma nationality. On 16 June 1998, the Constitutional Court issued an opinion dismissing the petition. On 8 April 1999, the Municipal Council of Nagov and the Municipal Council of Rokytovce held extraordinary meetings, attended by the District Prosecutor, and decided to revoke resolution No. 22 and resolution No. 21, respectively.

The Committee found that, although the wording of resolutions 21 and 22 referred explicitly to Roma previously domiciled in the municipalities concerned, other Roma would have been equally prohibited from settling, which represented a violation of Article 5 (d) (i) of the Convention.

Once all the documents and evidence had been gathered, the Committee delivered the following opinion on the merits:

1) Having received the full texts of resolutions 21 and 22 the Committee finds that, although their wording refers explicitly to Roma previously domiciled in the municipalities concerned, the context in which they were adopted clearly indicates that other Roma would have been equally prohibited from settling, which represented a violation of article 5 (d) (i) of the Convention.

2) The Committee notes, however, that the resolutions in question were rescinded in April 1999. It also notes that freedom of movement and residence is guaranteed under article 23 of the Constitution of the Slovak Republic.

3) The Committee recommends that the State party takes the necessary measures to ensure that practices restricting the freedom of movement and residence of Roma under its jurisdiction are fully and promptly eliminated.

The Committee's Opinion on racial discrimination was adopted in the case of L.R. and others ${ }^{10}$. The applicants were Mr L. R. and 26 other Slovak citizens of Roma ethnicity residing in the town of Dobšiná. They claimed that the Slovak Republic had violated their rights granted in Article 2 paragraph 1 points (a), (c) and (d); Article 4 paragraph (a); Article 5 paragraph (e) point (iii); and Article 6.

The circumstances of the case are, as follows: On 20 March 2002, the councillors of Dobšiná municipality adopted resolution No. 251-20/III-2002-MsZ, thereby approving what the petitioners described as a plan to construct low-cost housing for the Roma inhabitants of the town. More than 1800 Roma live in the town in what are described as "appalling" conditions, with most dwellings comprising thatched huts or houses made of cardboard and without drinking water, toilets or drainage or sewage systems. The councillors instructed the local mayor to prepare a project

10 Communication No. 31/2003 Committee on the Elimination of Racial Discrimination, CERD/ C/66/D/31/2003, 2005. Available at: https://undocs.org/CERD/C/66/D/31/2003 [last viewed August 28, 2019]. 
aimed at securing finance from a government fund set up expressly to alleviate Roma housing problems in the State party. Thereupon, certain inhabitants of Dobšiná and surrounding villages established a five-member "petition committee", led by the Dobšiná chairman of the Real Slovak National Party. The committee elaborated a petition with the following text:

I do not agree with the building of low cost houses for people of Gypsy origin on the territory of Dobšina, as it will lead to an influx of inadaptable citizens of Gypsy origin from the surrounding villages, even from other districts and regions. ${ }^{11}$

The petition was signed by some 2700 inhabitants of Dobšiná and deposited with the municipal council on 30 July 2002. On 5 August 2002, the council considered the petition and unanimously voted, "having considered the factual circumstances", to annul the earlier resolution by means of a second resolution, which included an explicit reference to the petition.

On 16 September 2002, in the light of the relevant law ${ }^{12}$, the petitioners' counsel requested the Rožñava District Prosecutor to investigate and prosecute the authors of the discriminatory petition, and to reverse the council's second resolution as it was based on a discriminatory petition. On 7 November 2002, the District Prosecutor rejected the request on the purported grounds of having no jurisdiction over the matter. The Prosecutor found that

11 Applicants' translation, which reflects exactly the text of the petition set out in the translated judgement of the Constitutional Court provided by the State party in annexure to its submissions on the merits. The State party suggests in its submissions on the merits that a more appropriate translation would be: "I do not agree with the construction of flats for the citizens of Gypsy nationality (ethnicity) within the territory of the town of Dobšiná, as there is a danger of influx of citizens of Gypsy nationality from surrounding area [sic] and even from other districts and regions."

12 Applicants refer to

(i) Article 1 of the Act on the Right of Petition, which provides: "A petition cannot call for a violation of the Constitution of the Slovak Republic and its laws, nor deny or restrict individual rights";

(ii) Article 12 of the Constitution, which provides:

(1) All human beings are free and equal in dignity and in rights. Their fundamental rights and freedoms are sanctioned; inalienable, imprescriptible and irreversible.

(2) Fundamental rights shall be guaranteed in the Slovak Republic to everyone regardless of sex, race, colour, language, belief and religion, political affiliation or other conviction, national or social origin, nationality or ethnic origin, property, descent or any other status. No one shall be aggrieved, discriminated against or favoured on any of these grounds.

(3) Everyone has the right to decide freely which national group he or she is a member of. Any influence and all manners of pressure that may affect or lead to a denial of a person's original nationality shall be prohibited.

(4) No injury may be inflicted on anyone, because of exercising his or her fundamental rights and freedoms.

(iii) Article 33 of the Constitution, which provides:

"Membership in any national minority or ethnic group may not be used to the detriment of any individual"; and

(iv) The Act on the Public Prosecution Office, which provides that the Prosecutor has a duty to oversee compliance by public administration bodies with laws and regulations, and to review the legality of binding regulations issued by public administration bodies. 
[..] the resolution in question was passed by the Dobsiná Town Council exercising its self-governing powers; it does not constitute an administrative act performed by public administration and, as a result, the prosecution office does not have the competence to review the legality of this act or to take prosecutorial supervision measures in nonpenal area. ${ }^{13}$

On 18 September 2002, the petitioners' counsel requested the Constitutional Court to determine whether Articles 12 and 33 of the Constitution, the Act on the Right of Petition and the Framework Convention for the Protection of National Minorities (Council of Europe) had been violated, annulling the council's second resolution and examine the legality of the petition. Further information was provided on two occasions at the request of the Court. On 5 February 2003, the Court, in closed session, held that the petitioners had provided no evidence that any fundamental rights had been violated by the petition or by the council's second decision. It stated that, as neither the petition nor the second resolution constituted legal acts, they were permissible under domestic law. It further stated that citizens had a right to petition regardless of the content of that petition.

The petitioners argued that the State party had violated Article 2, paragraph 1, subparagraph (a), by failing to "ensure that all public authorities and public institutions, national and local, shall act in conformity with this obligation" [to not engage in an act or practice of racial discrimination]. They argued, with reference to the Committee's jurisprudence, that a municipal council is a local public authority ${ }^{14}$ and that the council had engaged in an act of racial discrimination.

The Committee's Opinion contained the following observations: the Committee acting according to Article 14 paragraph 7 of the Convention on Elimination of All Forms of Discrimination, finds that the State party is in breach of its obligation under Article 2, paragraph 1 (a), Article 5, paragraph (d) (iii) and Article 6 of the Convention.

1) In accordance with Article 6 of the Convention, the State party is under an obligation to provide the petitioners with an effective remedy. In particular, the State party should take measures to ensure that the petitioners are placed in the same position that they were in upon adoption of the first resolution by the municipal council. The State party is also under an obligation to ensure that similar violations do not occur in the future.

2) The Committee wishes to receive, within ninety days, information from the Government of the Slovak Republic about the measures taken to give

13 Communication No. 31/2003 of the Committee on the Elimination of Racial Discrimination, CERD/C/66/D/31/2003, 2005. Available at: https://undocs.org/CERD/C/66/D/31/2003 [last viewed September 16, 2019].

${ }^{14}$ Communication No. 13/1998 of the Committee on the Elimination of Racial Discrimination. CERD/C/57/D/13/1998, 2000, Available at: https://minorityrights.org/wp-content/uploads/ old-site-downloads/download-372-Anna-Koptova-v.-Slovak-Republic.pdf and

https://www.equalrightstrust.org/sites/default/files/ertdocs//Koptova\%20v\%20Slovakia\%20_ access\%20to\%20good\%20and\%20services_.pdf [last viewed September 20, 2019]. 
effect to the Committee's Opinion. The State party is requested also to give wide publicity to the Committee's Opinion.

The last Opinion the Committee issued was in relation to the case of V.S. ${ }^{15}$ The applicant claimed to have experienced racial discrimination in accessing employment and violation of Article 2 (1) (a) and (c)-(e) and (2), in conjunction with Articles 5 and 6 of the Convention. She also claimed that the State party had failed to provide effective protection and remedy against acts of racial discrimination she had been subjected to.

The petitioner graduated from the University of Prešov in 2006 as a general teacher and history teacher. During her studies, she worked as a teaching assistant and carer in local elementary schools. On 18 June 2009, the applicant made speculative enquires regarding a teaching post in history and civic education at the I. B. Zoch Elementary School in Revúca, stating that, if no such post was available, she was willing to accept a post of a teaching assistant. The applicant alleges that, on the day when she submitted her application in person, she met with the school director, who told her that, instead of looking for a job, she should have children like other women of Roma origin. He allegedly added that, as a Roma woman, she would never get a job even if she tried to improve her qualifications through further study. The applicant felt humiliated and embarrassed by these comments, particularly because Roma were generally perceived as unwilling to work. On 26 July 2009, the director sent a letter to the applicant, informing her that there was no vacancy at the school but that her application would be kept on file in case a position became vacant. In September 2009, the applicant found out that a teaching assistant post had become vacant but that someone of non-Roma origin with fewer qualifications and less experience had been hired instead.

Suspecting that she had been discriminated against because of her Roma origin, the applicant filed a complaint with the Slovak National Centre for Human Rights (the Equality Centre) and requested that it undertake an independent inquiry into her case with regard to what happened at the I. B. Zoch Elementary School, but also at other elementary schools to which she had applied with no success. On 11 October 2010, the applicant initiated a civil complaint against the school before the District Court of Revúca, alleging a breach of the principle of equal treatment under Articles 9 et seq. of the 2004 Anti-discrimination Act. She requested an apology from the school and 10000 euros compensation for non-pecuniary damages. On 28 March 2011, the District Court dismissed her complaint. On 20 April 2011, the applicant filed an appeal with the Banská Bystrica Regional Court against the District Court decision. In the appeal, she stressed that she had made a prima facie case showing that the differential treatment was based on racial discrimination, and that the school therefore bore the burden of proof to demonstrate that no discrimination had taken place by providing reasonable and convincing arguments. She argued that the District Court had wrongly assessed

15 Communication No. 56/2014 of the Committee on the Elimination of Racial Discrimination, CERD/C/88/D/56/2014, 2016. Available at: https://undocs.org/en/CERD/C/88/D/56/2014 [last viewed August 28, 2019]. 
the facts and the evidence provided by the school and that its arguments should not have been considered reasonable and convincing. On 16 August 2011, the Regional Court affirmed the District Court decision and its assessment of the arguments presented by the school.

On 19 September 2011, the applicant filed for an extraordinary recourse with the Supreme Court against the Regional Court decision, claiming that her right to a fair trial had been violated, since the Regional Court had disregarded her arguments for appealing the decision of the District Court without properly examining them and that the decision of the Regional Court was therefore arbitrary. The applicant considered that, by interpreting the domestic legislation in a restrictive manner, the Regional Court had not provided effective protection of her rights.

On 25 January 2013, the applicant filed a constitutional complaint with the Constitutional Court, claiming that all the domestic courts had come to conclusions that were arbitrary, unjustifiable and unsustainable, resulting in a breach of her fundamental rights and freedoms guaranteed by the Constitution of Slovakia and the Convention (Arts. 5 and 6) and other international treaties. On 10 July 2013, the Constitutional Court dismissed the applicant's complaint as groundless. It reviewed the decisions of the domestic courts and came to the conclusion that they gave clear and comprehensible answers to all the relevant legal and factual issues relating to the judicial protection of the petitioner's rights as her arguments had been duly taken into account by the various courts, and that her rights had therefore not been violated.

The Committee considered the case, and after the observation of the government of the Slovak Republic, decided it was admissible. In the circumstances of the case, the Committee, acting under article 14 (7) (a) of the Convention on Elimination of All Forms of Racism, considered that the facts before it disclosed that the State party had violated articles 2 (1) (a) and (c), 5 (e) (i) and 6 of the Convention. The Committee recommended that the State party convey an apology to the petitioner and grant her adequate compensation for the damage caused by the abovementioned violations of the Convention.

Additionally, the Committee "urges the State party to consider ratifying those international human rights instruments that it has not yet ratified, in particular treaties with provisions that have direct relevance to communities that may be subjected to racial discrimination, including the International Convention on the Protection of the Rights of All Migrant Workers and Members of Their Families and the Optional Protocol to the Convention against Torture and Other Cruel, Inhuman or Degrading Treatment or Punishment."16

16 Concluding observations on the combined eleventh and twelfth periodic reports of Slovakia, CERD/C/SVK/CO/11-12, point 29, 2018. Available at: https://undocs.org/en/CERD/C/SVK/ $\mathrm{CO} / 11-12$ [last viewed August 28, 2019]. 


\section{Conclusions and recommendations}

This analysis shows that the Slovak Republic has violated its positive obligation regarding human rights, especially non-discrimination. We consider this violation to be systematic, as each of the periodic reviews refers to the violation of rights granted under the UN conventions. The Human Rights Council has repeatedly pointed to acts of discrimination on national, ethnical and gender grounds, despite the adoption of the Anti-discrimination Law and the sectoral legal regulation. The failures occur mainly in practice, as Slovakia is not able to fulfil its positive obligation in relation to the UN conventions on non-discrimination.

Having analysed the opinions, we conclude that apart from individual rights having been violated, compensation and just satisfaction are also a problem. The Committee's opinions do not have the status of judgements. Nevertheless, they are adopted and published in the form of a review of the international human rights' treaty obligation, which has, as stated in Article 7, paragraph 5 of the Constitution, supremacy over national law.

The UN Committees have the competency to conduct reviews in relation to the obligation arising from the international human rights treaty. According to Optional Protocol No. 3 to the Convention on the Rights of the Child, these committees are quasi-judicial in character. Although the Committees' opinions may seem to be non-legally binding in character, they have to be considered within the wider context of the aforementioned additional protocol and the constitutional obligation stated in Article 1, paragraph 3 of the Constitution of the Slovak Republic: "The Slovak Republic recognizes and honours general rules of international law, international treaties by which it is bound and its other international obligations". In cases where Slovakia is not fulfilling its obligations, as indicated by the UN Committee's opinions, the responsibility can be enforced.

\section{BIBLIOGRAPHY}

\section{Literature}

1. Fridrich B. (ed.), Ústavné garancie ludských práv [Constitutional guarantees of human rights]. Bratislava: Law Faculty, CU, 2013.

2. Fridrich B. Human Rights and Freedoms in the Constitution of the Slovak Republic. In: Constitutional system of the EU member state: The Slovak Republic. Bratislava: VO UK, 2018, p. 101

\section{Legislative acts}

1. Act No. 365/2004 of 20 May 2004 on equal treatment in certain areas and protection against discrimination, amending and supplementing certain other laws (Anti-Discrimination Act). Available at: https://www.ilo.org/wcmsp5/groups/public/---ed_protect/---protrav/---ilo_ aids/documents/legaldocument/wcms_128039.pdf [last viewed September 20, 2019].

2. Constitution of the Slovak Republic, Constitutional Act No. 460/1992 Coll. Available at: http://www.slovakia.org/sk-constitution.htm [last viewed September 20, 2019]. 
3. Communication No. 13/1998 of the Committee on the Elimination of Racial Discrimination. CERD/C/57/D/13/1998, 2000. Available at: https://minorityrights.org/wp-content/ uploads/old-site-downloads/download-372-Anna-Koptova-v.-Slovak-Republic.pdf and https://www.equalrightstrust.org/sites/default/files/ertdocs//Koptova\%20v\%20Slovakia\% 20_access\%20to\%20good\%20and\%20services_.pdf [last viewed September 20, 2019].

4. Communication No. 31/2003 of the Committee on the Elimination of Racial Discrimination, CERD/C/66/D/31/2003, 2005, Available at: https://undocs.org/CERD/C/66/ D/31/2003 [last viewed September 16, 2019].

5. Communication No. 56/2014 of the Committee on the Elimination of Racial Discrimination, CERD/C/88/D/56/2014, 2016. Available at: https://undocs.org/en/CERD/C/88/D/56/ 2014 [last viewed August 28, 2019].

6. Concluding observations on the combined eleventh and twelfth periodic reports of Slovakia, CERD/C/SVK/CO/11-12, point 29 2018. Available at: https://undocs.org/en/CERD/C/ SVK/CO/11-12 [last viewed August 28, 2019].

7. European Commission: October infringements package: key decisions. Available at: https:// europa.eu/rapid/press-release_INF-19-5950_en.htm, 2019 [last viewed October 10, 2019].

8. Finding of the Constitutional Court of the Slovak Republic, file ref. No. II. ÚS 5/02, decision of 21 May 2003. Collection of CC SR Findings, $1^{\text {st }}$ half of the year, 2003, p. 284.

9. Finding of the Constitutional Court of the Slovak Republic, file ref. No. II. ÚS 91/1991, decision of 16 December 1999. Collection of CC SR Findings, $2^{\text {nd }}$ half of the year, 1999, p. 672

10. UN Charter. Available at: https://treaties.un.org/doc/publication/ctc/uncharter.pdf [last viewed October 10, 2019].

11. UN General Assembly Resolution No. 60/251 of 2006. Available at: https://www2.ohchr. org/english/bodies/hrcouncil/docs/A.RES.60.251_En.pdf [last viewed October 10, 2019]. 